\title{
Syntheses of Bioinspired Trisporphyrin Scaffoldings from Stepwise Suzuki Coupling Strategies
}

\author{
Jean-Michel Camus, ${ }^{a}$ Pierre D. Harvey ${ }^{\mathrm{a}, \mathrm{b}}$ and Roger Guilard ${ }^{\mathrm{a}}$ \\ Dedicated to Irina P. Beletskaya on the occasion of her anniversary
}

a'Institut de Chimie Moléculaire de l'Université de Bourgogne (ICMUB,UMR 6302), Université de Bourgogne, Dijon, France ${ }^{\mathrm{b}}$ Département de Chimie, Université de Sherbrooke, 2550 Boulevard de l'Université, Sherbrooke, Québec, Canada

${ }^{\circledR}$ Corresponding author E-mail: Roger.Guilard@u-bourgogne.fr

\begin{abstract}
This review presents the synthetic approach for the design of tris(macrocycles) as bio-inspired models for light harvesting devices in plants and photosynthetic bacteria based on cofacial bisporphyrins and a porphyrin unit attached as a side arm. Two types of tris(porphyrins) are described herein depending on the nature of the chromophores of the cofacial bis(porphyrins). The synthetic methodology of a series of trimeric models relies on the versatility of the porphyrin ring acting as a building block, and on successive Suzuki coupling reactions. Various pathways to access such models are presented as the selective and stepwise substitution processes involving different borylated porphyrin synthons can provide either meso-meso-linked linear intermediates or cofacial homo- or hetero-bismacrocycle units. This efficient methodology also allows for the flexibility and fine tuning since different bridges and spacers can be used in the designed trimers.
\end{abstract}

Keywords: Suzuki coupling, light harvesting models, energy transfer, cofacial bis(porphyrins), porphyrinic dyads and triads.

\section{Стратегия поэтапного кросс-сочетания Сузуки в синтезе био-миметических трис-порфириновых структур}

\author{
Ж.-М. Камю, ${ }^{a}$ П. А. Харвей, ${ }^{\mathrm{a}, \mathrm{b}}$ Р. Гиляр ${ }^{\mathrm{a}}$
}

Посвящается Ирине Петровне Белецкой по случаю её юбилея

\footnotetext{
anstitut de Chimie Moléculaire de l'Université de Bourgogne (ICMUB,UMR 6302), Université de Воurgognе, Дижон, Франuия 'Département de Chimie, Université de Sherbrooke, 2550 Boulevard de l'Université, Sherbrooke, Квебек, Канада

@E-mail: Roger.Guilard@u-bourgogne.fr
}

В обзоре рассмотрены стратегии синтетического дизайна трис(макроциклов) как природныхмоделей светопоглощающих систем растений и фотосинтетических бактерий, основанных на кофациальных биспорфиринах с дополнительным порфириновым фрагментом. Описаны два типа трис-порфиринов, различающихся природой порфириновых хромофоров. Синтетическая методология сборки трис-порфириновых моделей основывается на универсальности порфиринового кольца в качестве строительного блока и на последовательных реакциях кросс-сочетания Сузуки. В обзоре рассмотрены различные синтетические пути создания таких модельных соединений путем селективного и поэтапного замещения с использованием в качестве синтонов различных борзамещзенных порфиринов, которые могут дать либо мезо-мезо-связанные линейные интермедиаты либо кофациальные гомо- или гетеро-бисмакроциикические единищы. Эта эффективная методология позволяет проводить также тонкую структурную модификацию, путём использования различных мостиков и спейсеров в создаваемых тримерах.

Ключевые слова: Кросс-сочетание Сузуки, светопоглощающие системы, перенос энергии, кофациальные бис(порфирины), порфириновые диады и триады. 


\section{Introduction}

Recent advances in transition metal catalysis reactions were appropriately applied to the functionalization of porphyrins, hence opening up a wide range of skeleton modulations of the porphyrin core. Numerous examples of catalytic reactions dealt with the carbon-carbon or carbon-heteroatom $(\mathrm{N}, \mathrm{S}, \mathrm{O}, \mathrm{P})$ bond formation at the meso- or $\beta$-positions of the porphyrin macrocycle and the palladium(0)-catalyzed reactions revealed to be a powerful tool for the functionalization of porphyrins. ${ }^{[1]}$ Particularly, the Suzuki and Sonogashira coupling processes occupy a large part of the literature reports in this field in comparison to the Stille, Negishi or Heck reactions. Since the pioneering work of Therien and his collaborators, ${ }^{[2]}$ bromoporphyrin turned out to be a substrate of choice for a wide range of palladium catalyzed reactions. Indeed, this convenient compound can undergo the palladium( $(0)$ oxidative addition and reductive elimination by a nucleophile releases of the functionalized porphyrin. Moreover, bromoporphyrin can also be metalated under Masuda conditions for instance, ${ }^{[3]}$ making the porphyrin more nucleophilic, which can then react with a wide range of brominated compounds. ${ }^{[4]}$ Regioselective iridium(I)-catalyzed $\mathrm{C}-\mathrm{H}$ bond activation allows for the direct $\beta$-borylation of the porphyrin ring without the preparation of brominated intermediate, as a required preliminary step for the synthesis of substituted meso-porphyrins. ${ }^{[5]}$ These features are highly relevant for the synthesis of direct carbon-carbon linked multiporphyrinic arrays. ${ }^{[6]}$ With these synthetic approaches, many combinations of multiporphyrin assemblies can be prepared by changing the nature of porphyrin, the position (i.e. meso- and $\beta$-) and the nature of the linking unit between the different macrocycles and consequently affecting the characteristics of the arrays, which in turn can act as optical devices, sensors or solar cells. ${ }^{[7]}$ Photosystems in plants and photosynthetic bacteria exhibit spectacular rates of excitation energy migration (also called exciton) and energy transfers hence displaying high efficiency of energy flow between the antenna complexes and the central special pair of the reaction center. ${ }^{[8]}$ The natural special pair consists of two chlorophyll or bacteriochlorophyll chromophores placed as a slipped dimer, which appear in various orientations from organism to organism. Indeed, beside the distance between the cofacial macrocycles varying from 3.2 to $5.0 \AA$ depending on the photosystem, $\pi-\pi$ interactions can be either maximized or suppressed. Nowadays, the synthesis and design of bio-inspired dyads remains a subject of great interest. The biophysical properties of light harvesting devices of various natural photosystems, along with many mainly covalently linked polyporphyrin arrays and assemblies built upon coordination linkages as chemical models, were previously investigated. ${ }^{[7 a, 7 b, 9]}$ Noteworthy, the face-to-face bismacrocyclic units can be covalently linked together by either a flexible chain or by a rigid bridge. Since the earlier investigations on rigidly held cofacial bisporphyrins in the 1990 's, ${ }^{[10]}$ their properties have been published by us and other for the last decade. ${ }^{[1]}$ Indeed over the past decade, the synthesis and the photophysical properties of a series of cofacial energy donor-acceptor dyads were described and the tuning of the $\mathrm{C}_{\text {meso }}-\mathrm{C}_{\text {meso }}$ distance with different rigid spacers affects the rate of energy transfer, as outlined in Figure 1.

Light energy conversion into chemical energy in plants and photosynthetic bacteria first requires an efficient funneling of the excitation energy into the redox center that is the special pair. A large series of antenna chromophores surrounds the special pair, and hence ensuring a good flow of excitation energy into the latter prior to the primary electron transfer. In order to investigate these complex natural systems, trimeric chemical models can be designed and synthesized according to the reaction scheme presented in Figure 2 where structural modifications can conveniently be performed on the bridge, the porphyrins and the spacer. Previous investigations on the preparation of such an architecture require tedious syntheses where an anthracenyl bridge (DPA) was introduced to link the two porphyrin units in a cofacial fashion. ${ }^{[12]}$ In order to get flexibility in the molecular design and better overall chemical yields, we now report a short review on a methodology for the stepwise synthesis of such trimeric models. This approach is based on successive Suzuki couplings as an alternative and efficient procedure for the synthesis of a series of trimeric
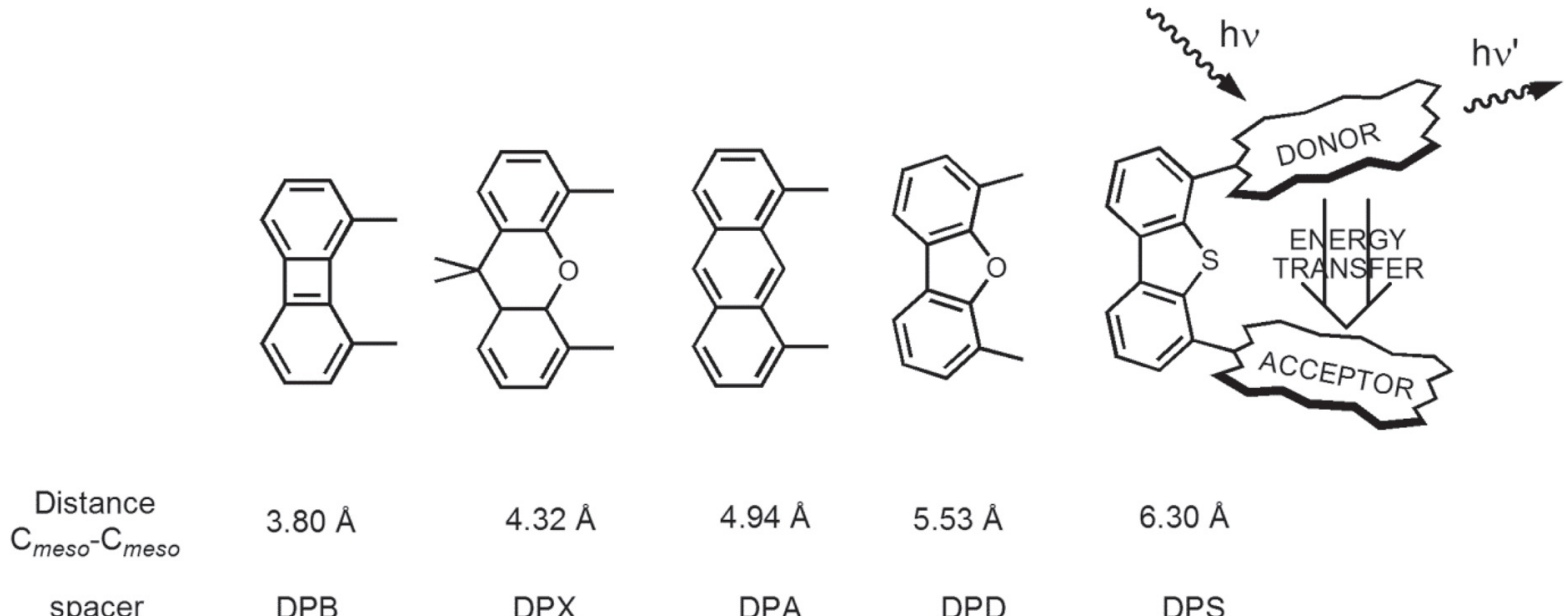

$3.80 \AA$

DPB
$4.32 \AA$

DPX
$4.94 \AA$

DPA
$5.53 \AA$

DPD
$6.30 \AA$

DPS

Figure 1. Molecular structures of 5 cofacial heterobisporphyrins along as a function of the rigid spacer and the $\mathrm{C}_{\text {meso }}-\mathrm{C}_{\text {meso }}$ distances. (DPB :biphenylene, DPX : xanthene, DPA : anthracene, DPD : dibenzofuran, DPS : dibenzothiophene). 
models for artificial special pair-antenna dyads incorporating a rigid bridge (DPB, DPA and DPS). Porphyrin acts as a versatile building block as it can provide different units within the trimer, Por 2 and Por 3 for instance. A spacer can be introduced to move away the free base (Por 3) from the cofacial assembly.

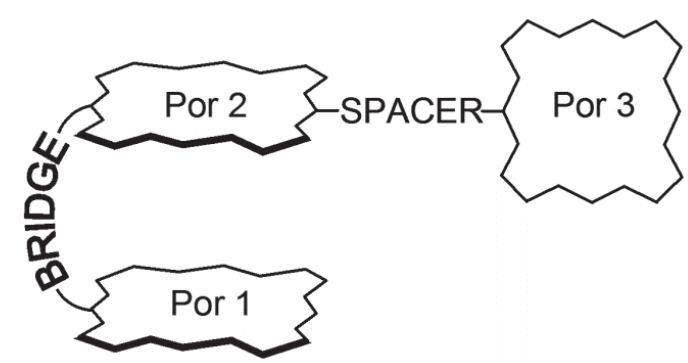

Figure 2.General structure of the trimeric models for artificial special pair-antenna.

Depending on the nature of the desired substitution on the porphyrin ring, notably meso- vs $\beta$-substituted macrocycle, their position within the trimer and the presence or not of a spacer, different synthesis pathways have been developed. These are summarized in Scheme 1. Borylated porphyrins are then key starting materials for the intermediate synthesis of a cofacial bisporphyrin or of the linear dimer. ${ }^{[6,13]}$ Despite numerous publications on the use of borylated porphyrins, it is quite surprising that only a few examples have been reporting, prior to our work, the successive palladium catalyzed reaction as a straightforward procedure for porphyrin's functionalization at the meso position. ${ }^{[6,14]}$

Depending on the nature of the porphyrin used in the cofacial dimer, two types of trimers can be designed, which are described below (Figure 3). Indeed, when three different porphyrin units are used, the system can be described as energy donor1-donor2-acceptor system in which a direct through space energy transfer between the donor1 and acceptor can take place, or a through space process between donor 1 and donor 2 occurs then a quick through bond energy transfer process between donor2 and acceptor operates.
This means that donor2 acts as a relay unit for the overall process donor $1 \rightarrow$ acceptor. This section on donor1-donor2acceptor triads concerns the DPA- and DPS-containing assemblies 1, 2 and 3 (Figure 3). Concurrently, when the units of the cofacial bisporphyrin are identical and closely spaced while a third (free base) porphyrin is placed as a side arm, the resulting trimeric chemical model is then a dyad composed of an artificial special pair linked to an antenna. For this purpose, a second section is devoted to the synthesis of trisporphyrins built upon a biphenylene bridge (DPB), namely 4, 5 and $\mathbf{6}$.

\section{The Synthesis of DPA- and DPS-Containing Energy Transfer Triads}

For triads based on a cofacial $\beta$-alkyl porphyrin and a meso-porphyrin (1, 2 and 3, Figure 3), the key precursors area suitably functionalized as $\beta$-alkyl porphyrins $\mathbf{7 a - c}$ and porphyrins 8a-b (Scheme 2 and 3). ${ }^{[15]}$ Compounds 7a-c are obtained by acid-catalyzed condensation of aldehyde (8-bromoanthracene-1-carbaldehyde for 7a and 4-bromo6-formyldibenzothiophene for $\mathbf{7 b}, 7 \mathbf{c}$ ) with 1 equiv. of octaalkyl a,c-biladiene dihydrobromide according to standard literature procedures ${ }^{[16]}$ and provide the required spacer for the construction of the cofacial assembly (Scheme 2).

As illustrated in Scheme 3, porphyrin 8 acts as a versatile synthon since it provides the intermediate monobrominated porphyrin 9, mono- and bis-borylatedporphyrins $\mathbf{1 0}$ and 11. Upon bromination with one or two equivalents of $\mathrm{N}$-bromosuccinimide (NBS), compound 7 and dibrominated porphyrins can readily be obtained or can be converted with pinacolborane into borylated compounds under Masuda conditions. This bromination/metalation/borylation sequence allows for a selective functionalization of the meso position giving access to any required Suzuki substrate.

Both pathways involve the synthesis of either linear or cofacial dimers prior to the synthesis of the desired trimers and, again, Suzuki coupling reveals to be a powerful tool for this purpose (Scheme 4). The first route involves a C-C coupling between bis-borylated porphyrins $\mathbf{1 1}$ and a suitable brominated compound bearing the DPA or DPS bridge $\mathbf{7 a - b}$

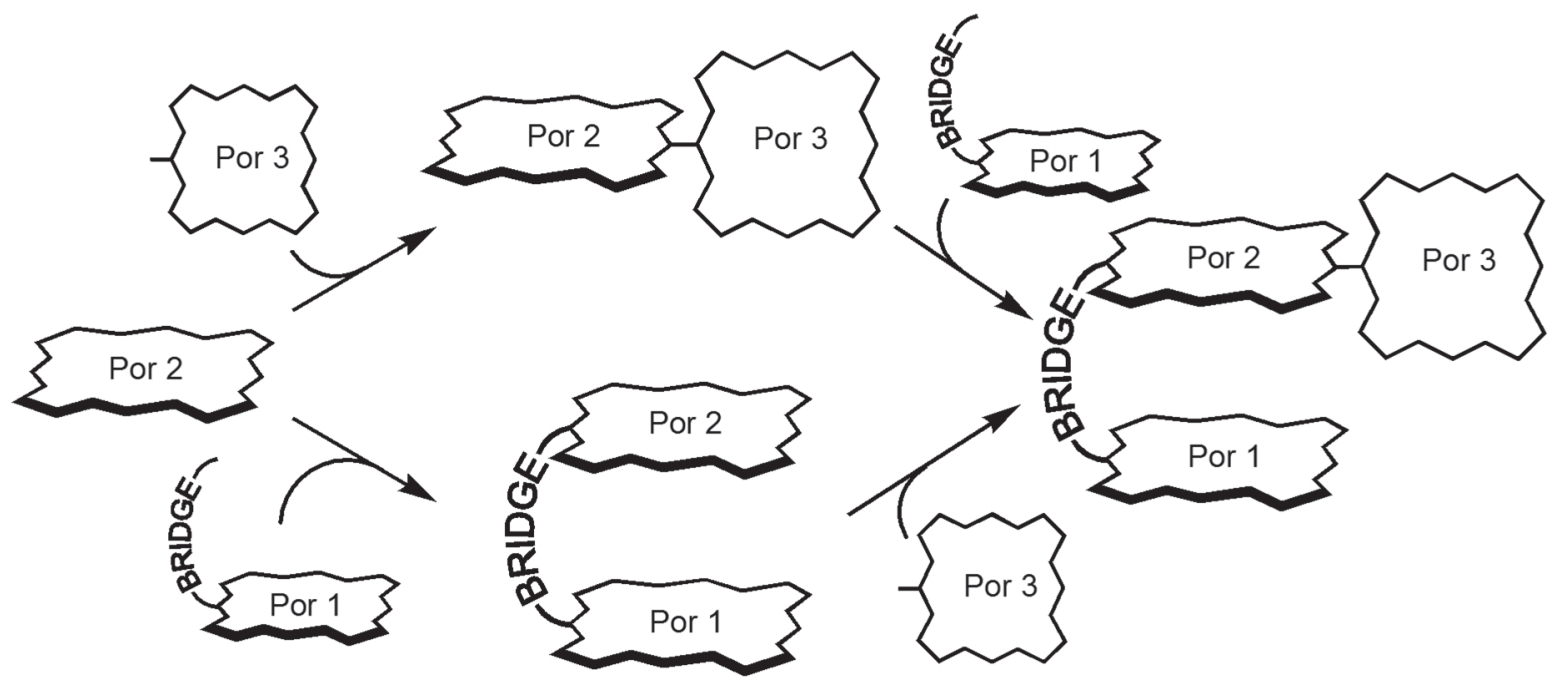

Scheme 1.Two different pathways, based on the sequence of reactants for the synthesis of trimers. 


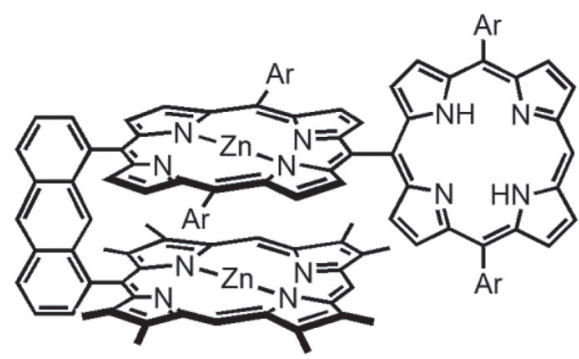

1

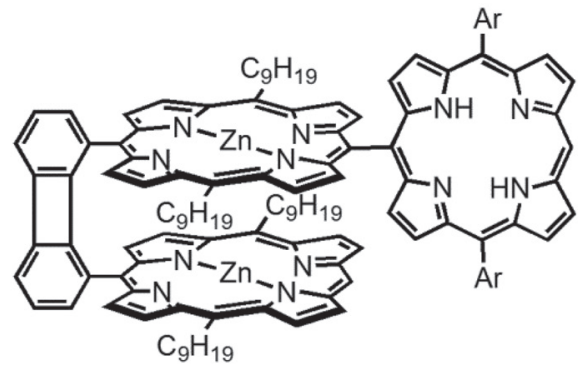

4

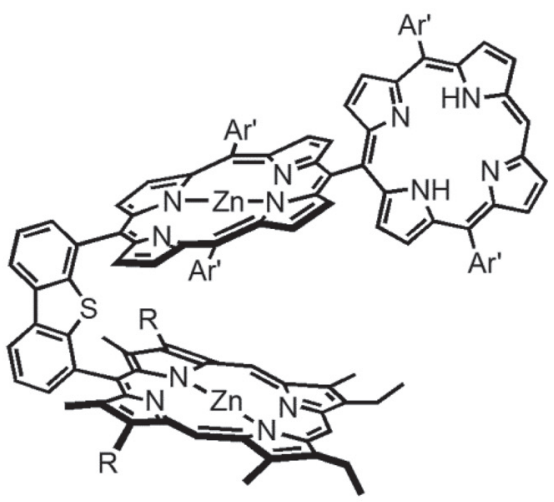

$2 \mathrm{R}=\mathrm{Me}$

$3 \mathrm{R}=\mathrm{Et}$

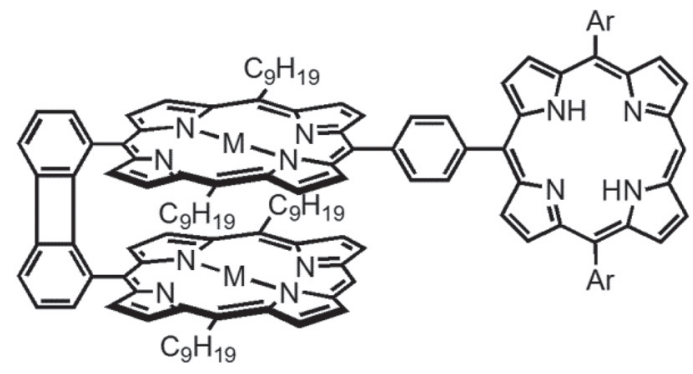

$5 \mathrm{M}=\mathrm{Zn}$

$6 \mathrm{M}=\mathrm{Mg}$

Figure 3. Structures of the different triads described in this review. Ar=3,5-di-(tert-butyl)-phenyl, $\mathrm{Ar}{ }^{\prime}=4-\mathrm{C}_{6} \mathrm{H}_{4} \mathrm{Et}$.
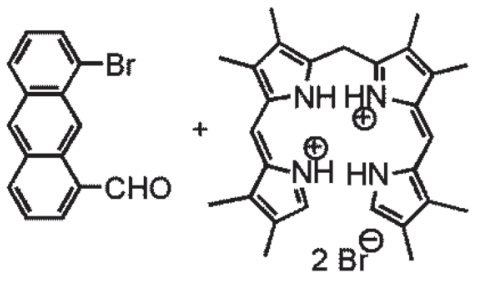

1) P.TSA

2) $\mathrm{Zn}(\mathrm{OAC})_{2}$<smiles>O=Cc1cccc2c1sc1c(Br)cccc12</smiles><smiles></smiles>

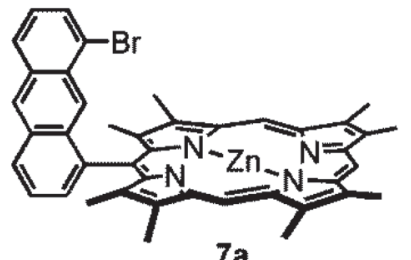

$7 \mathbf{a}$

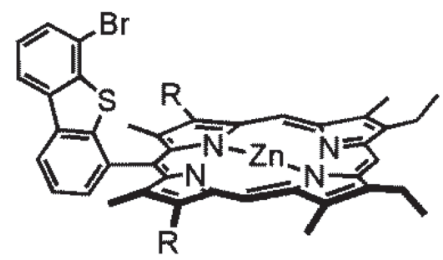

$7 b, 7 c$

$\mathrm{R}=\mathrm{Me}, \mathrm{Et}$

Scheme 2. Synthesis of the $\beta$-alkyl porphyrins 7a-c.

and provides the cofacial dimer 12a-c. After a rapid survey of the literature for previous used catalytic conditions, a mixture of toluene and DMF in the presence of a catalytic amount $(10 \mathrm{~mol} \%)$ of $\mathrm{Pd}\left(\mathrm{PPh}_{3}\right)_{4}$ and 1.5 equiv of $\mathrm{Cs}_{2} \mathrm{CO}_{3}$ at $90{ }^{\circ} \mathrm{C},{ }^{[12 \mathrm{a}]}$ was found to provide selectivity and in good yields (58-65\%). These yields are similar to that reported for the related dibenzofuran- and dibenzothiophene-containing species. ${ }^{[13 b]}$ The byproducts resulting from the well-known reductive deborylation of porphyrin derivatives occurring under $\operatorname{Pd}(0)$ catalysis conditions may be detected by MALDI-TOF analysis, but appear as very minor products. So a more selective catalyst is consequently not required. ${ }^{[17]}$ Due to the presence of boronic ester function on the desired compounds, which confers a different polarity from the side products and reagents, the target dimers are easily purified on silica gel.

Dyads 12a-c can be submitted to a second coupling reaction with the free base monomer $\mathbf{9 a , b}$. In comparison 

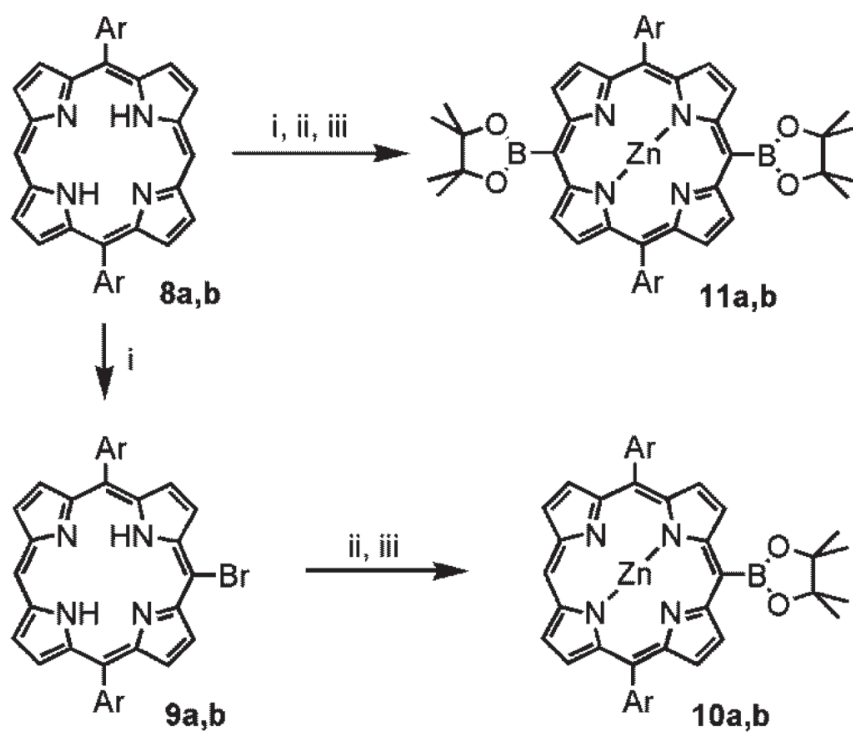

a, $\mathrm{Ar}=3,5$-di(tert-butyl)-phenyl b, $\mathrm{Ar}=4-\mathrm{C}_{6} \mathrm{H}_{4}-\mathrm{Et}$

Scheme 3. Synthesis of 9-11a,b. i) NBS, ii) $\mathrm{Zn}(\mathrm{OAc})_{2} \cdot 2 \mathrm{H}_{2} \mathrm{O}$, iii) Pinacolborane, $\mathrm{PdCl}_{2}\left(\mathrm{PPh}_{3}\right)_{2}, \mathrm{NEt}_{3}$.

with the experimental conditions used in the synthesis of the dimers, a higher ratio free base/dimer was necessary to lower the amount byproducts (see below) and a longer reaction time was required to ensure a satisfactory yield (29-48\%). Nevertheless, longer reaction times (up to $48 \mathrm{~h}$, for $\mathbf{1 2 a}$ ) turned out to be not necessary since incomplete conversions of the starting dimers 12a-c were observed as well as the formation of the side product originating from the deborylation of 12a-c. Steric hindrance caused by dimer moiety may hamper the transmetalation step with the palladated porphyrin and therefore explains the difference in isolated yields for DPAand DPS-containing trimers. Noteworthy, changing the experimental conditions, such as the nature of the catalyst $\left(\mathrm{Pd}_{2}(\mathrm{dba})_{3}, \mathrm{PdCl}_{2}\left(\mathrm{Ph}_{3} \mathrm{P}\right)_{2}\right)$ or the reagent ratio, did not result in a significant increase of the conversion. ${ }^{[14 \mathrm{a}]}$

Another route for the synthesis of trimers 1-3 was investigated and involved the formation of the intermediate linear meso-linked bis-porphyrin 13. Despite the tremendous work of Osuka and his collaborators on meso-meso linked multiporphyrin arrays, ${ }^{[8 c, 18]}$ palladium catalyzed reaction has surprisingly emerged only recently as a promising and efficient tool to the silver(I) promoted coupling of monomers. ${ }^{[6 \mathrm{~d}, 6 \mathrm{e}, 13 \mathrm{a}, 19,20]}$ In order to take advantage of high yields and selectivity of this method, the first boryl group in $\mathbf{1 1}$ is substituted by carbon-carbon coupling with the bromoporphyrin 9 . The fine tuning of reagents ratios affects the functionalization of both borylated moieties of $\mathbf{1 1}$ lowering the formation of an undesired linear trimeric compound. The borylated linear bis(porphyrins) 13b,c are obtained in $c a .60$ $\%$ yield and are easily purified by column chromatography from the reagents and side-products as, again, the presence of boronic ester function confers polarity differences of the porphyrin derivatives. Subsequent Suzuki reactions between the dimers 13b,c and bromoporphyrin $\mathbf{6}$ provided triads 1 and 3 in a higher yields ( $35 \%$ and $55 \%$ ) in comparison to the route described above.

\section{The Synthesis of DPB-Containing Trimers: Artificial Special Pair-Antenna Energy Transfer Dyads}

Triads having two identical porphyrin units separated by a short biphenylene bridge in an artificial special pair coupled to free base porphyrin residue, are readily designed using this methodology in order to provide more advanced chemical models for the corresponding natural systems. ${ }^{[21]}$ For this purpose, 5,15-bis(nonyl)porphyrin 8c acts as a versatile synthon providing mono and bis(borylated) porphyrin 10c and 11c, respectively, according to the well-established bromination/metalation/borylation procedures. $^{[3,13]}$ These building blocks minimize the possible steric hindrance in cofacial dimers since the biphenylene (DPB) link is a shorter bridge with a $\mathrm{C}_{\text {meso }}-\mathrm{C}_{\text {meso }}$ distance of $3.8 \AA .^{[22]}$

Applying the strategy outlined in Scheme 6, successive Suzuki couplings were also performed for the stepwise synthesis of porphyrin bearing the spacer (1,4-benzene), the cofacial borylated dimer and the target trimer, 14, 15, and 4, respectively. Following the experimental conditions used for previous systems $\left(\mathrm{Pd}\left(\mathrm{PPh}_{3}\right)_{4}\right.$ as catalyst, $\mathrm{Cs}_{2} \mathrm{CO}_{3}$ as the base in a DMF-toluene mixture, the coupling between 1,8dibromobiphenylene and 5,15-dinonylporphyrin boronate 10c provides the porphyrin 14 (in $94 \%$ yield when using a two-fold excess of $\mathbf{1 0 c}$ ). It can subsequently react with porphyrin diboronate 11c under carbon-carbon coupling reaction conditions to give the borylated cofacial dimer 15. Better yields (48\%) were obtained by a progressive introduction of the borylated reagent onto the preformed palladium intermediate.

Upon using a $1 / 1$ or a $2 / 1$ ratio of bromoporphyrin 9a with respect to boronate $\mathbf{1 2}$, only trace amounts of $\mathbf{4}$ along with unreacted starting reagents were isolated. An increase of the reaction time or the amount of catalyst and different catalytic systems (i.e. by varying the nature of palladium precursors $\left(\mathrm{Pd}\left(\mathrm{PPh}_{3}\right)_{4}, \mathrm{Pd}_{2}(\mathrm{dba})_{3}, \mathrm{PdCl}_{2}\left(\mathrm{Ph}_{3} \mathrm{P}\right)_{2}\right)$ and bases $\left(\mathrm{KOH}, \mathrm{Cs}_{2} \mathrm{CO}_{3}, \mathrm{Ba}(\mathrm{OH})_{2}\right)$ in DMF or toluene-DMF (2:1) mixtures at $90-100{ }^{\circ} \mathrm{C}$ ) were stubbornly unsuccessful. The low reactivity of Suzuki reaction is known to be affected by steric hindrance, caused here by the cofacial dimer. ${ }^{[23]}$ The yield of the target trimer $\mathbf{4}$ was actually found to be critically dependent on the reagents' ratio. Indeed, product 4 was isolated in $50 \%$ yield when using a two-fold excess of boronate 15 with respect to bromoporphyrin 9a using $\mathrm{Pd}\left(\mathrm{PPh}_{3}\right)_{4}$ as the catalyst (with $\mathrm{Cs}_{2} \mathrm{CO}_{3}$, in DMF/toluene; Scheme 7). At first glance, the full conversion of 9a within 8 $\mathrm{h}$ at $90{ }^{\circ} \mathrm{C}$ seems surprising, but is consistent with a previous work which demonstrated that an excess of borylated reagents is required to ensure the quantitative consumption of the sterically hindered arylbromide and the reduction of $\mathrm{Pd}(\mathrm{II})$ to $\mathrm{Pd}(0)$ species. ${ }^{[24]}$

The alternative route involving the coupling of the borylated meso-meso dimer 16 with 14 was investigated. However, regardless of the reaction conditions, no trimer 4 was observed, while dimer 16 underwent an undesired deborylation side reaction and an aryl-aryl exchange process reaction yielding the linear meso-meso derivatives $\mathbf{1 7}$ and $\mathbf{1 8}$, respectively ${ }^{[25]}$ (Scheme 8).

Taking advantage of the versatility of borylated bisporphyrin 15 , new models similar to trimer 4 were obtained by 
Bioinspired Trisporphyrin Scaffoldings

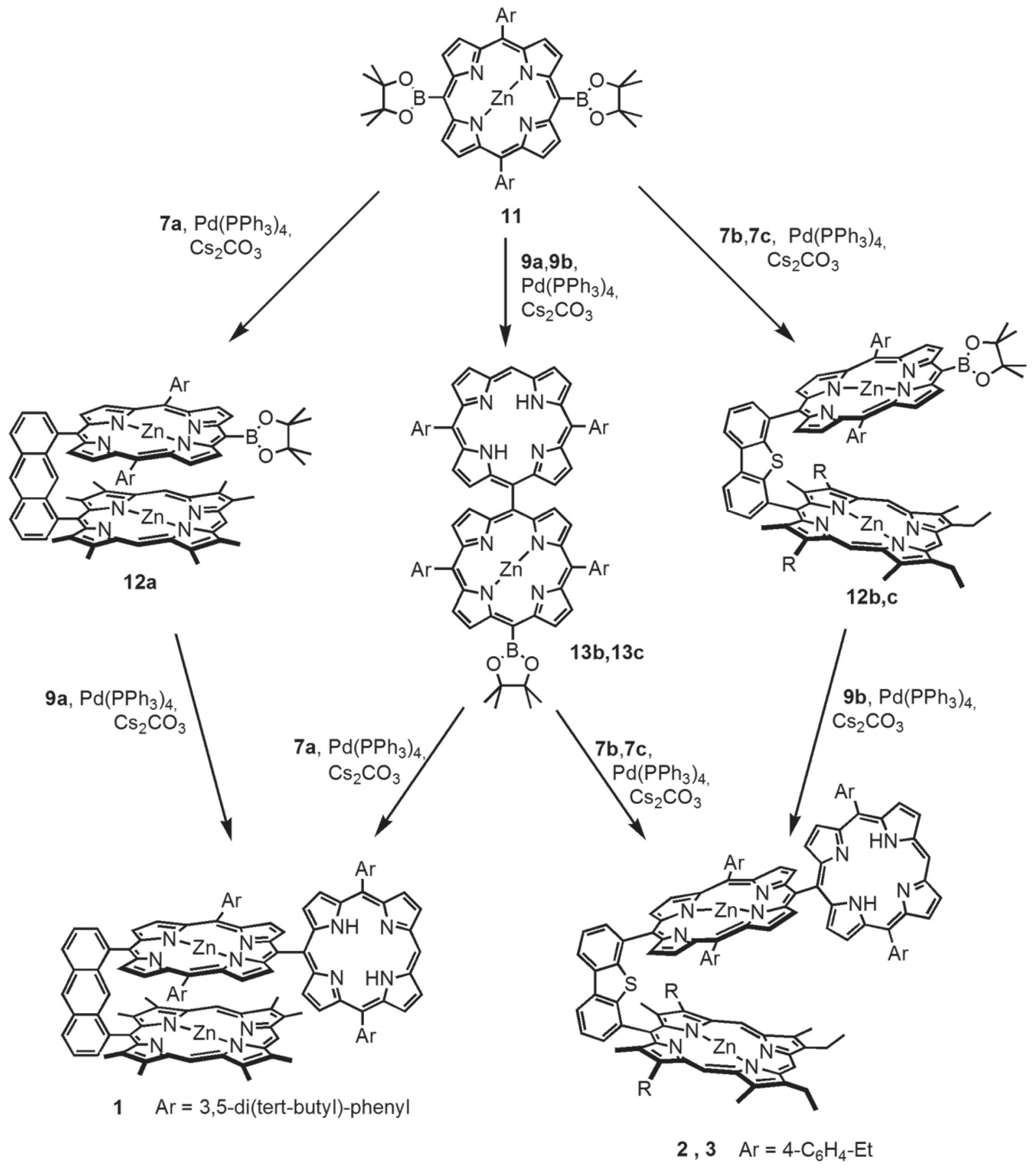

Scheme 4. Different pathways for the synthesis of triads 1-3.

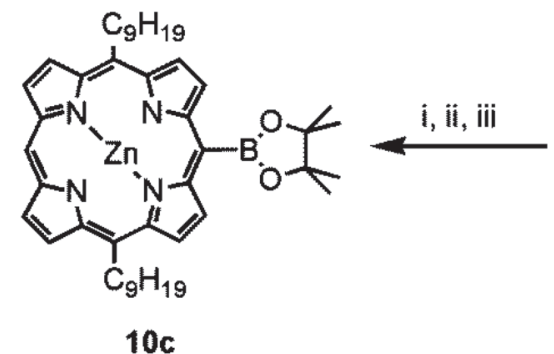

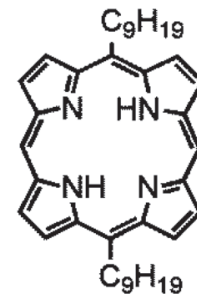

$8 c$

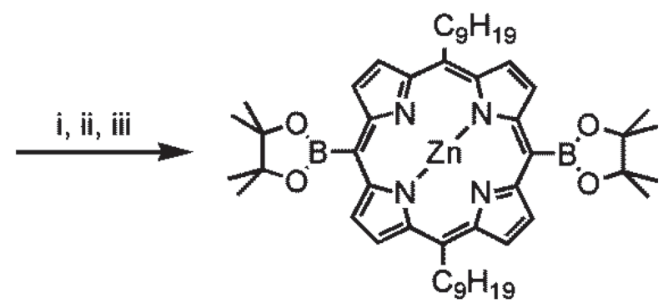

$11 \mathrm{c}$

Scheme 5. Synthesis of 10b and 10c. i) NBS, ii) $\mathrm{Zn}(\mathrm{OAc})_{2} \cdot 2 \mathrm{H}_{2} \mathrm{O}$, iii) Pinacolborane, $\mathrm{PdCl}_{2}\left(\mathrm{PPh}_{3}\right)_{2}, \mathrm{NEt}_{3}$. 


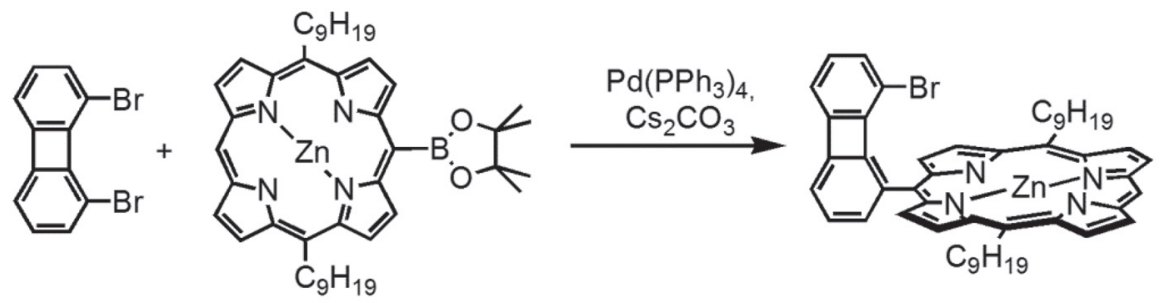

14

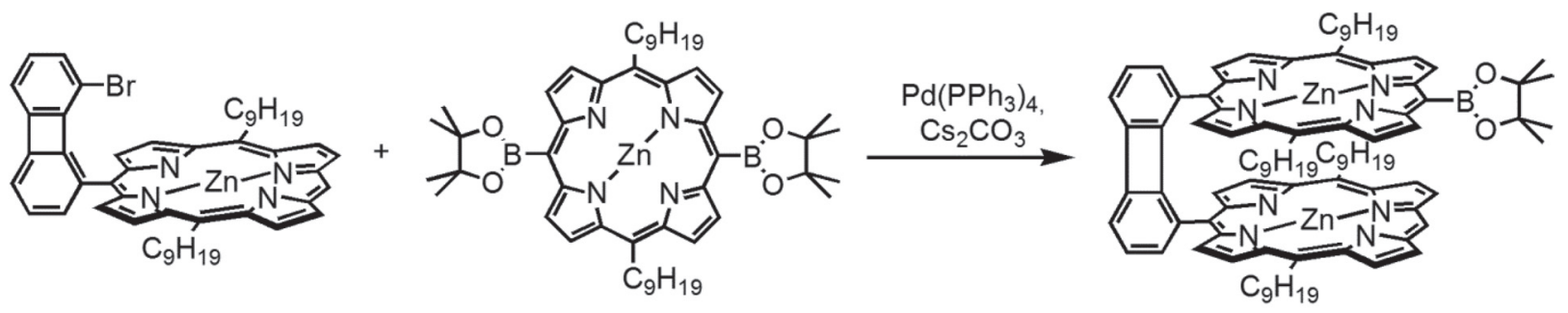

15

Scheme 6. Synthesis of $\mathbf{1 4}$ and $\mathbf{1 5 .}$

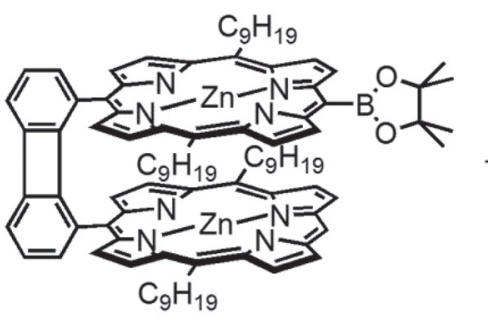

15

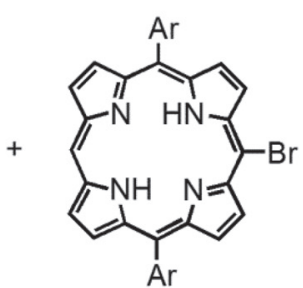

9a
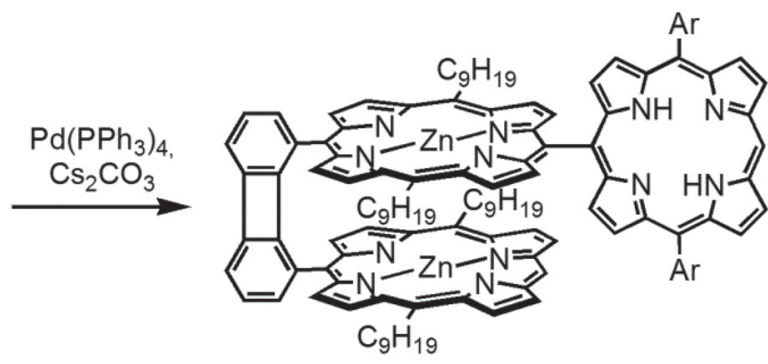

4

Ar $=3,5$-di(tert-butyl)-phenyl

Scheme 7. Synthesis of 4.
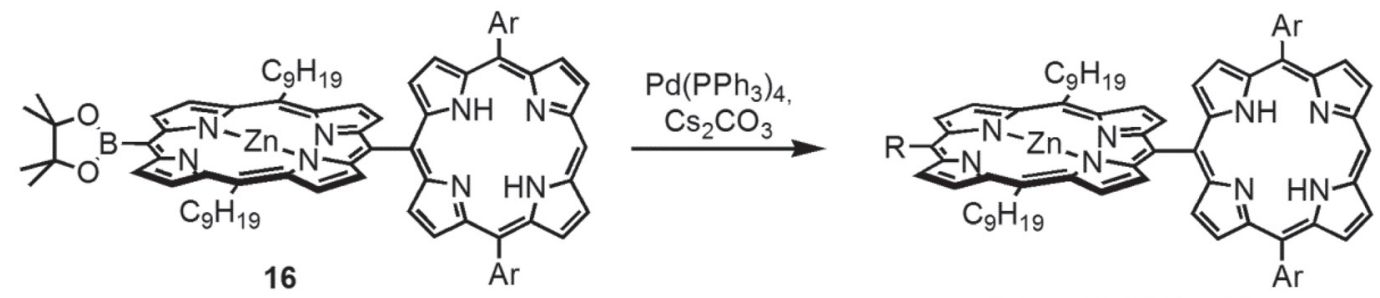

$17 \mathrm{R}=\mathrm{H}, 18 \mathrm{R}=\mathrm{Ph}$

Scheme 8. Reaction showing the formation of the undesired compounds $\mathbf{1 7}$ and $\mathbf{1 8}$.

introducing a benzene spacer between the free base porphyrin and the artificial special pair, i.e. the DPB-containing cofacial bisporphyrin moiety. ${ }^{[21 b-c]}$ First, the substitution of the boryl group of bis(porphyrin) $\mathbf{1 5}$ by porphyrin 19 under Suzuki coupling conditions provides trimer 5. As anticipitated, the $\mathrm{Pd} / \mathrm{PPh}_{3}$ catalyst provides low conversion $(5 \%)$ as the steric hindrance of the cofacial dimer affects the reactivity of the catalyst. Specific ligands were used to achieve Suzuki couplings of sterically hindered substrates. ${ }^{[26]}$ Using the experimental conditions described above for the synthesis of triads 1-3 and changing the phosphine, the $S$-PHOS ligand provides a more reactive catalyst as the borylated reagent was totally consumed after $15 \mathrm{~h}$ of reaction time and trimer 5 was isolated with a $43 \%$ yield.

Subsequent metalation can then occur at the free base of the trimer but the substitution of both zinc atom requires a transmetalation step of the borylated dimer $\mathbf{1 5}$ prior to the formation of desired trisporphyrin. Indeed, the bisporphyrin residue can easily be demetalated in acidic media according to Scheme 10 . The resulting cofacial free base $\mathbf{2 0}$ is actually resistant to hydrolysis since it is isolated with a $62 \%$ yield. After the introduction of magnesium atoms, the metalated 
15

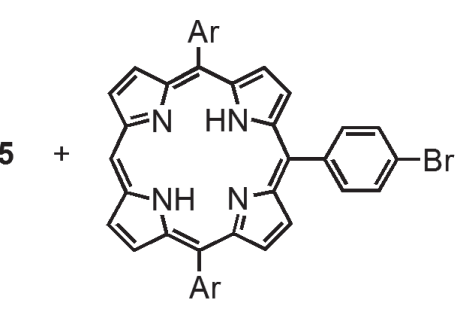

19

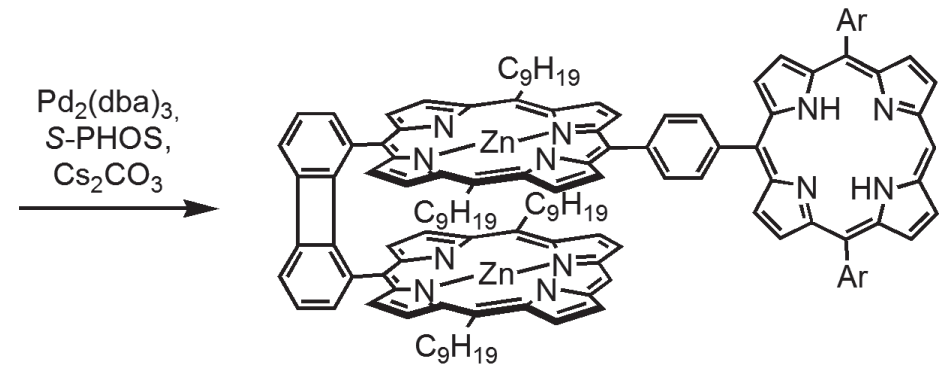

$5 \quad$ Ar $=3,5-$ di (tert-butyl)phenyl

Scheme 9. Synthesis of trimer 5.

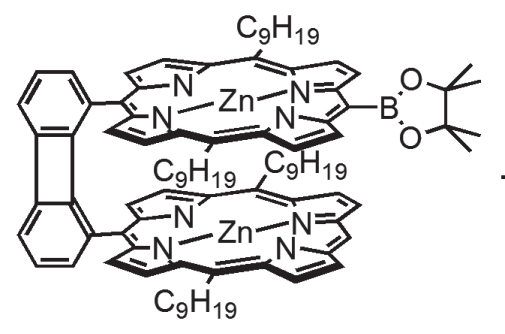

15

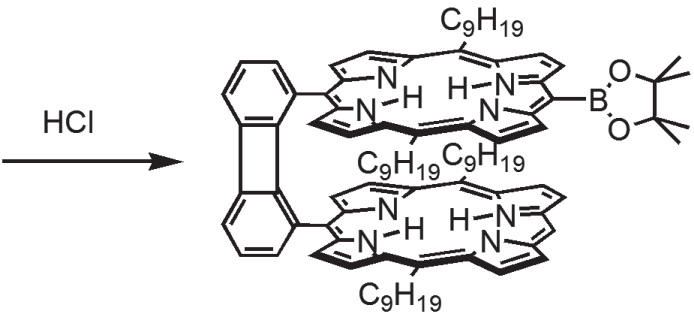

20 $\mathrm{Mg}_{2}\left(\mathrm{OEt}_{2}\right), \mathrm{NEt}_{3}$

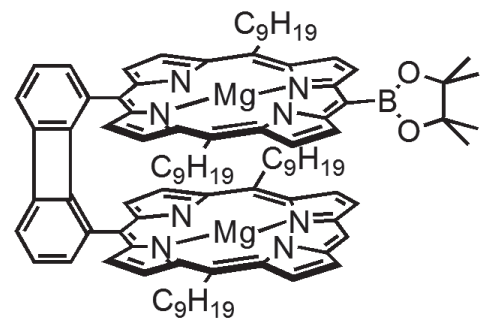

21
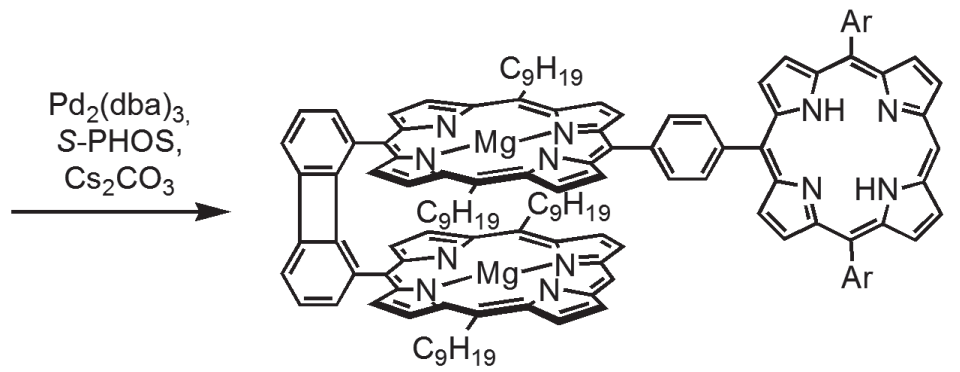

6

$\operatorname{Ar}=3,5-d i($ tert-butyl)phenyl

Scheme 10. Synthesis of 20, 21 and 6.

dimer $\mathbf{2 1}$ is conveniently stable during the coupling conditions as it reacts with porphyrin $\mathbf{1 7}$, similarly to $\mathbf{1 5}$, to provide the target trimer $\mathbf{6}$, which is the $\mathrm{Mg}_{2}$-analog of trimer $\mathbf{5}$.

\section{Final Remarks}

Several porphyrin assemblies used to model light harvesting devices have been synthesized, thanks to a highly convenient stepwise Suzuki couplings strategy. This efficient methodology is based on successive substitutions of boryl moieties on porphyrins providing bisporphyrins and target trimers. This method also allows for flexibility since different bridges and spacers can be introduced to tune the photophysical properties of trisporphyrins. Versatile porphyrins can then be used for various reaction pathways providing intermediate borylated linear and cofacial dimers. By further functionalization of the cofacial dyads, a free base was anchored as a third porphyrin unit through a direct 


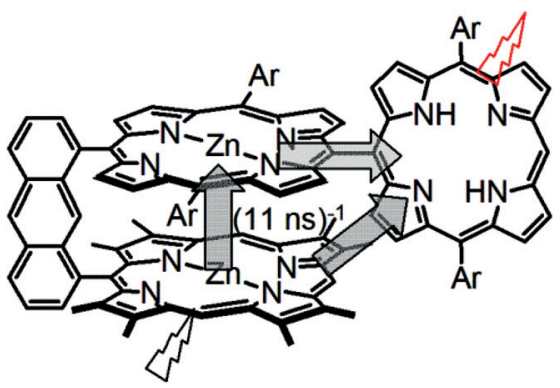

1

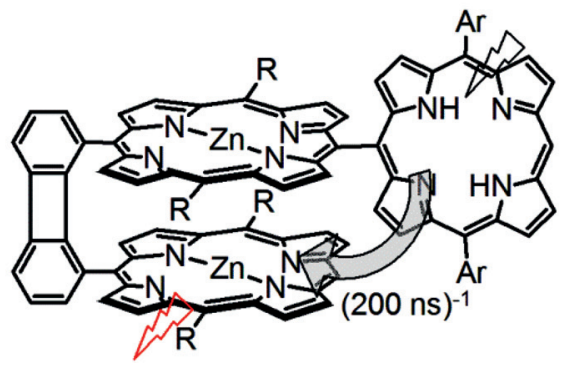

4

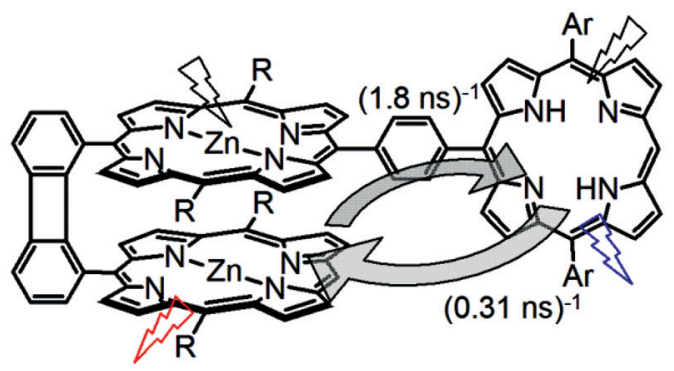

5

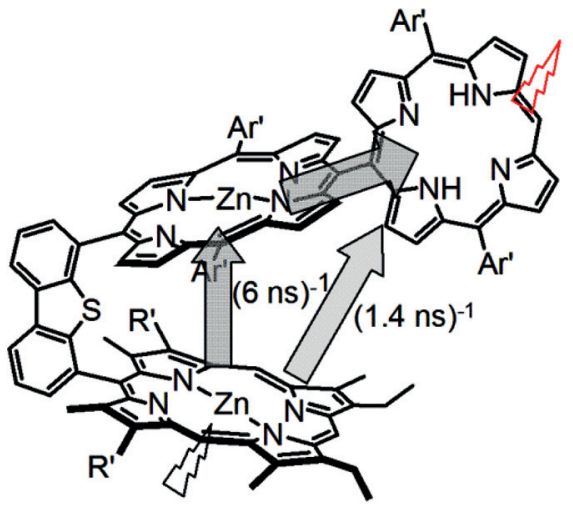

2,3

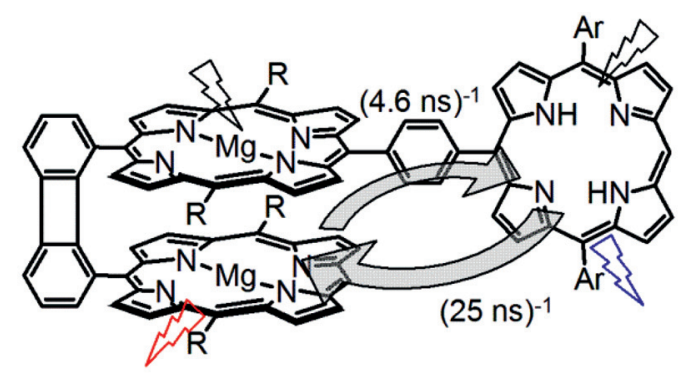

6

Figure 4. Singlet energy transfer observed in trimers 1-6 $\left(\mathrm{Ar}=3,5-\mathrm{di}(\right.$ tert-butyl $)$ phenyl, $\mathrm{Ar}$ ' = 4-ethylphenyl, $\left.\mathrm{R}=\mathrm{C}_{8} \mathrm{H}_{19}, \mathrm{R}^{\prime}=\mathrm{Me}, \mathrm{Et}\right)$.

$\mathrm{C}_{\text {meso }}-\mathrm{C}_{\text {meso }}$ bond or a spacer could be incorporated at the mesopositions of both porphyrins. This valuable approach is a convenient method for the preparation of meso-meso linked porphyrin building blocks for synthetic applications. This powerful synthetic methodology allows for some structural modifications of trimers, which actually exhibit different photophysical events, such as absorption, emission and energy transfers as illustrated in Figure 4. Beside the roles of the chromophores, the rates and the pathways of singlet energy transfer are found to be strongly dependent on the model.

Regarding the DPA- and DPS-containing models 1-3, energy transfer between the donor and the free base acceptor can occur directly through space between two chromophores and can use an intermediate acceptor (i.e. donor2) as a relay in a cascade process. This path is notably 5 times more efficient than the direct path. ${ }^{[15 b]}$ Because of longer distances (2 and 3 vs 1), energy transfer rates are logically slower in DPS-containing based models. In contrast to triads 1-3, the free base in the DPB-containing models 4-6 acts as the donor and the cofacial moiety acts as one chromophore. The fastest energy transfer rate was detected for trimer 4 . The presence of a benzene spacer in $\mathbf{5}$ and $\mathbf{6}$ induces a slower $\mathrm{k}_{\mathrm{ET}}\left(\mathrm{S}_{1}\right)$ energy transfer in comparison with 4. Moreover, equilibrium of singlet energy transfer (i.e. singlet energy transfer operating in both directions and cycling) takes place between the antenna and the special pair in $\mathbf{5}$ and $\mathbf{6}$ with rates depending on metal centers and the temperature.

Acknowledgements. PDH thanks the Agence National de la Recherche (ANR) for a Research Chair of Excellence and the Natural Science and Engineering Research Council of Canada (NSERC) for research grants. JMC and RG thank the Centre National de la Recherche Scientifique.

\section{References}

1. (a) Sergeeva N.N., Senge M.O., Ryan A. Organometallic C-C Coupling Reactions for Porphyrins. In: Handbook of Porphyrin Science (Kadish K.M., Smith K.M., Guilard R., Ed.) Singapore: World Scientific, 2010, Vol. 3, 325-365. (b) Fields K.B., Ruppel J.V., Snyder N.L., Zhang X.P. Porphyrin Functionalization via Palladium-Catalyzed Carbon-Heteroatom Cross-Coupling Reactions. In: Handbook of Porphyrin Science (Kadish K.M., Smith K.M., Guilard R., Ed.) Singapore: World Scientific, 2010, Vol. 3, 367-427. (c) Beletskaya I.P., Tyurin V.S., Uglov A., Stern C., Guilard R. Survey of Synthetic Routes for Synthesis and Substitution in Porphyrins. In: Handbook of Porphyrin Science (Kadish K.M., Smith K.M., Guilard R., Ed.) Singapore: World Scientific, 2012, Vol. 23, 81-279. 
2. DiMagno S.G., Lin V.S.Y., Therien M.J. J. Am. Chem. Soc. 1993, 115, 2513-2515.

3. Murata M., Watanabe S., Masuda Y. J. Org. Chem. 1997, 62, 6458-6459.

4. Hyslop A.G., Kellett M.A., Iovine P.M., Therien M.J. J. Am. Chem. Soc. 1998, 120, 12676-12677.

5. Hata H., Shinokubo H., Osuka A. J. Am. Chem. Soc. 2005, 127, 8264-8265.

6. (a) Nakamura Y., Hwang I.-W., Aratani N., Ahn T.K., Ko D.M., Takagi A., Kawai T., Matsumoto T., Kim D., Osuka A. J. Am. Chem. Soc. 2005, 127, 236-246. (b) Song J., Aratani N., Kim P., Kim D., Shinokubo H., Osuka A. Angew. Chem. Int. Ed. 2010, 49, 3617-3620. (c) Cheng F., Zhang S., Adronov A., Echegoyen L., Diederich F. Chem. Eur. J. 2006, 12, 60626070. (d) Wu C.-A., Chiu C.-L., Mai C.-M., Lin Y.-S., Yeh C.-Y. Chem. Eur. J. 2009, 15, 4534-4537. (e) Götz D.C.G., Bruhn T., Senge M.O., Bringmann G. J. Org. Chem. 2009, 74, 8005-8020.

7. (a) Holten D., Bocian D.F., Lindsey J.S. Acc. Chem. Res. 2002, 35, 57-69. (b) Kim D., Osuka A. Acc. Chem. Res. 2004, 37, 735. (c) Aratani N., Kim D., Osuka A. Acc. Chem. Res. 2009, 42, 1922-1934. (d) Gust D., Moore T.A., Moore A.L. Acc. Chem. Res. 2001, 34, 40-48. (e) Gust D., Moore T.A., Moore A.L. Acc. Chem. Res. 2009, 42, 1890-1898. (f) Fukuzumi S. Artificial Photosynthetic Systems Composed of Porphyrins and Phtalocyanines. In: Handbook of Porphyrin Science (Kadish K.M., Smith K.M., Guilard R., Ed.) Singapore: World Scientific, 2010, Vol. 46, 183-243.

8. Green B.R., Parson W.W. Light-Harvesting Antennas in Photosynthesis (in Advances in Photosynthesis and Respiration) Dordrecht: Kluwer Academic Publishers, 2003, 544 p.

9. (a) Wojaczynski J., Latos-Grazynski L. Coord. Chem. Rev. 2000, 204, 113-171. (b) Prodi A., Indelli M.T., Kleverlaan C.J., Alessio E., Scandola F. Coord. Chem. Rev. 2002, 229, 51-58. (c) Chambron J.-C., Collin J.-P., Dixon I., Heitz V., Salom-Roig W.J., Sauvage J.-P. J. Porphyrins Phthalocyanines 2004, 8, 82-92. (d) Kobuke Y. J. Porphyrins Phthalocyanines 2004, 8, 156-174.

10. (a) Osuka A., Nagata T., Maruyam K. Chem. Lett. 1991, 481-484. (b) Osuka A., Maruyama K., Mataga N., Asahi T., Yamazaki I., Tamai N., Nishimura Y. Chem. Phys. Lett. 1991, 181, 413-418. (c) Staab H.A., Carell T. Angew. Chem. Int. Ed. 1994, 33, 1466-1468.

11. (a) Deng Y., Chang C.K., Nocera D.G. J. Am. Chem. Soc. 2000, 122, 410-411. (b) Chang C.J., Baker E.A.,Pistorio B.J., Deng Y., Loh Z.-H., Miller S.E., Carpenter S.D., Nocera D.G. Inorg. Chem. 2002, 41, 3102-3109. (c) Fletcher J.T., Therien M.J. J. Am. Chem. Soc. 2000, 122, 12393-12394. (d) Fletcher J.T., Therien M.J. J. Am. Chem. Soc. 2002, 124, 4298-4311. (e) Harvey P.D., Proulx N., Martin G., Drouin M., Nurco D.J., Smith K.M., Bolze F., Gros C.P., Guilard R. Inorg. Chem. 2001, 40, 4134-4142. (f) Harvey P.D., Stern C., Gros C.P., Guilard R. Coord. Chem. Rev. 2007, 251, 401-428. (g) Harvey P.D., Stern C., Guilard R. Bio-inspired Molecular Devices Based on Systems Found in Photosynthetic Bacteria. In: Handbook of Porphyrin Science (Kadish K.M., Smith K.M., Guilard R., Ed.) Singapore: World Scientific, 2011, Vol. 11, 1-179.

12. Osuka A., Nakajima S., Maruyama K., Magata N., Asahi T., Yamazaki I., Nishimura Y., Ohno T., Nozaki K. J. Am. Chem. Soc. 1993, 115, 4577-4589.
13. (a) Aratani N., Osuka A. Org. Lett. 2001, 3, 4213-4216. (b) Chng L.L., Chang C.J., Nocera D.G. J. Org. Chem. 2003, 68, 4075-4078. (c) Fendt L.-A., Stöhr M., Wintjes N., Enache M., Jung T.A., Diederich F. Chem. Eur. J. 2009, 15, 11139-11150.

14. (a) Maeda C., Yamaguchi S., Ikeda C., Shinokubo H., Osuka A. Org. Lett. 2008, 10, 549-552. (b) Nakamura Y., Jang S.Y., Tanaka T., Aratani N., Lim J.M., Kim K.S., Kim D., Osuka A. Chem. Eur. J. 2008, 14, 8279-8289. (c) Fazekas M., Pintea M., Senge M.O., Zawadzka M. Tetrahedron Lett. 2008, 49, 2236-2239. (d) Ljungdahl T., Pettersson K., Albinsson B., Martensson J. J. Org. Chem. 2006, 71, 1677-1687.

15. (a) Filatov M.A., Guilard R., Harvey P.D. Org. Lett. 2010, 12, 196-199. (b) Camus J.-M., Aly S.M., Fortin D., Guilard R., Harvey P.D. Inorg. Chem., submitted.

16. Kadish K.M., Ou Z., Shao J., Gros C.P., Barbe J.-M., Jerome F., Bolze F., Burdet F., Guilard R. Inorg. Chem. 2002, 41, 3990-4005.

17. Davis N.K.S., Pawlicki M., Anderson H.L. Org. Lett. 2008 , 10, 3945-3947.

18. (a) Aratani N., Osuka A., Kim Y.H., Jeong D.H., Kim D. Angew. Chem. Int. Ed. 2000, 39, 1458-1462. (b) Hori T., Peng X., Aratani N., Takagi A., Matsumoto T., Kawai T., Yoon Z.S., Yoon M.-C., Yang J., Kim D., Osuka A. Chem. Eur. J. 2008, 14, 582-595. (c) Nakamura Y., Jang S.Y., Tanaka T., Aratani N., Lim J.M., Kim K.S., Kim D., Osuka A. Chem. Eur. J. 2008, 14, 8279-8289.

19. Deng Y., Chang C.K., Nocera D.G. Angew. Chem. Int. Ed. 2000, 39, 1066-1067.

20. Bringmann G., Gulder T.A.M., Gehrke T.H., Kupfer T., Radacki K., Braunschweig H., Heckmann A., Lambert C. J. Am. Chem. Soc. 2008, 130, 17812-17825.

21. (a) Filatov M.A., Laquai F., Fortin D., Guilard R., Harvey P.D. Chem. Commun. 2010, 46, 9176-9178. (b) Camus J.-M., Aly S.M., Langlois A., Guilard R., Harvey P.D. Chem. Commun. 2013, DOI: 10.1039/c3cc38740b. (c) Camus J.-M., Langlois A., Aly S.M., Guilard R., Harvey P.D. J. Porphyrins Phthalocyanines, accepted.

22. (a) Fillers J.P., Ravichandran K.G., Abdalmuhdi I., Tulinsky A., Chang C.K. J. Am. Chem. Soc. 1986, 108, 417-424. (b) Collman J.P., Hutchison J.E., Lopez M.A., Tabard A., Guilard R., Seok W.K., Ibers J.A., L'Her M. J. Am. Chem. Soc.1992, 114, 9869-9877. (c) Bolze F., Gros C.P., Drouin M., Espinosa E., Harvey P.D., Guilard R. J. Organomet. Chem. 2002, 643644, 89-97.

23. Yin J., Rainka M.P., Zhang X.-X., Buchwald S.L. J. Am. Chem. Soc. 2002, 124, 1162-1163.

24. Moreno-Manax M., Perez M., Pleixats R. J. Org. Chem. 1996, 61, 2346-2351.

25. (a) Goodson F.E., Wallow T.L., Novak B.M. J. Am. Chem. Soc. 1997, 119, 12441-12453. (b) Kwong F.Y., Lai C.W., Chan K.S. Tetrahedron 2004, 60, 5635-5645.

26. (a) Wolfe J.P., Buchwald S.L. Angew. Chem., Int. Ed. 1999, 38, 2413-2416. (b) Wolfe J.P., Singer R.A., Yang B.H., Buchwald S.L. J. Am. Chem. Soc. 1999, 121, 9550-9561. (c) Barder T.E., Walker S.D., Martinelli J.R., Buchwald S.L. J. Am. Chem. Soc. 2005, 127, 4685-4696. (d) Martin R., Buchwald S.L. Acc. Chem. Res. 2008, 41, 1461-1473. (e) Cammidge A.N., Scaife P.J., Berber G., Hughes D.L. Org. Lett. 2005, 7, 3413-3416. (f) Ali H., van Lier J.E. Tetrahedron Lett. 2009, 50, 337-339. 